\title{
DÜBLIN
}

Technological University Dublin

ARROW@TU Dublin

\section{Exploring the curricular content of engineering ethics education in Ireland}

\author{
Diana Adela Martin \\ Technological University Dublin, dianaadela.martin@tudublin.ie \\ Eddie Conlon \\ Technological University Dublin, edward.conlon@tudublin.ie \\ Brian Bowe \\ Technological University Dublin, Brian.Bowe@TUDublin.ie
}

Follow this and additional works at: https://arrow.tudublin.ie/engineduccon

Part of the Other Education Commons, and the Other Engineering Commons

\section{Recommended Citation}

D. A. Martin, E. Conlon and B. Bowe, "Exploring the curricular content of engineering ethics education in Ireland," 2020 IFEES World Engineering Education Forum - Global Engineering Deans Council (WEEFGEDC), 2020, pp. 1-5, doi: 10.1109/WEEF-GEDC49885.2020.9293664.

This Conference Paper is brought to you for free and open access by the Engineering: Education and Innovation at ARROW@TU Dublin. It has been accepted for inclusion in Conference papers by an authorized administrator of ARROW@TU Dublin. For more information, please contact arrow.admin@tudublin.ie, aisling.coyne@tudublin.ie,gerard.connolly@tudublin.ie.

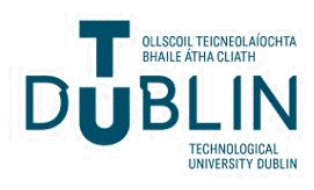


See discussions, stats, and author profiles for this publication at: https://www.researchgate.net/publication/345316477

\section{Exploring the curricular content of engineering ethics education in Ireland}

Conference Paper $\cdot$ November 2020

DOI: 10.1109/WEEF-GEDC49885.2020.9293664

\section{CITATIONS}

2

3 authors:

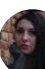

Diana Adela Martin

Eindhoven University of Technology

12 PUBLICATIONS 27 CITATIONS

SEE PROFILE

(1)

Brian Bowe

Technological University Dublin - City Campus

70 PUBLICATIONS 596 CITATIONS

SEE PROFILE

\section{READS}

128

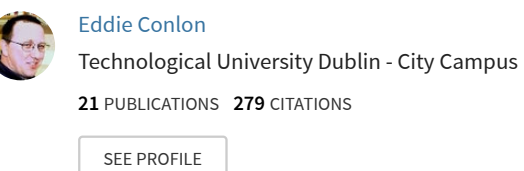

Some of the authors of this publication are also working on these related projects:

Book project: Engineering, Social Sciences, and the Humanities: Have their Conversations Come of Age? View project

Engineering Ethics Education View project 


\section{Exploring the curricular content of engineering ethics education in Ireland}

\author{
Diana Adela Martin \\ College of Engineering and Built \\ Environment \\ TU Dublin \\ Dublin, Ireland \\ dianaadela.martin@tudublin.ie
}

\author{
Eddie Conlon \\ College of Engineering and Built \\ Environment \\ TU Dublin \\ Dublin, Ireland
}

\author{
Brian Bowe \\ Office of Quality Assurance and \\ Academic Programme Records \\ TU Dublin \\ Dublin, Ireland
}

\begin{abstract}
Our contribution aims to determine the main curricular themes employed in engineering ethics instruction. In the use of the term "curricular content", the study is guided by an understanding of curriculum in terms of the syllabus content of a specific discipline or set of units taught to students [1]. The research study has been conducted in cooperation with the national accrediting body Engineers Ireland and includes 23 Engineering programmes from 6 institutions in Ireland that underwent accreditation between 2017-2019. The research method employed is a documentary analysis of the materials prepared by the programmes for accreditation or made available on the website of all participant programmes. The findings reveal three themes amenable to the implementation of ethics across the curriculum (sustainability, Health and Safety, legislation), which are present in a variety of courses, such as technical courses, design courses, professional formation courses, capstone projects, legal studies courses, business studies courses, as well as in work placement. The curricular themes purporting to professional ethics, responsibility and the societal context of engineering have a strong presence in courses of professional formation, which have the role of acculturating students to the profession of engineering and its norms. Thus the main conclusion of our study highlights the need for a hybrid implementation of ethics across the curriculum as well as in dedicated single modules, in order to promote a comprehensive engineering ethics education.
\end{abstract}

Keywords-engineering ethics education, curriculum content, documentary analysis

\section{INTRODUCTION}

The literature on engineering ethics education notes a diversity of approaches in regards to the content of engineering ethics education. We find coverage such as professional codes, ethical theories, ethical heuristics, plagiarism science and technology studies, humanist readings and service learning ([2]; [3]; [4]; [5]). However, not all types of coverage is considered of "equal value for the implicit goals of enhancing divergent thinking, helping engineers to see their work through the eyes of the broader community" [3]. Colby and Sullivan [6] highlight the uneven coverage of key issues, claiming that engineering ethics education shows a strong emphasis on professional codes, while the broader mission and implications of engineering are neglected. Polmear et al [7] note there are geographical differences in terms of coverage, linked to the formulation of the accreditation criterion dedicated to ethics. As such, a higher percentage of non-US Anglo and Western European educators were found to teach sustainability and environmental issues in their courses compared to US respondents, while educators based in the US teach codes of ethics, ethics in design, and safety more often than those in Western Europe [7]. Nevertheless, Atesh et al [5] claim that in engineering programmes in the UK, there is a higher focus on issues such as plagiarism and honesty than on respect for life, law and public good, reflected in the higher importance attributed by students to these former issues.

Mitcham and Englehardt [8] point out that while more attention is being given in engineering ethics to professional codes, the critical histories of ideas about engineering and engineering ethics are neglected. In their view, discussions about public safety, health and welfare should be complemented by reflection on the historical and social character of public safety, public health and societal welfare. Bielefeldt et al [9] also highlight the poor understanding of the extent to which macroethical topics are included in engineering ethics education. This is consistent with the difference in perception between instructors and students in regards to the coverage of ethical issues revealed in the survey by Holsapple et al [10]. Despite the fact that faculty describe their instruction as including not only codes but also a nuanced treatment of complex issues, students reported hearing "simplistic, black-and-white messages about ethics" ([10], p.101).

The aim of the research study is to examine the curricular content used in engineering ethics education in the context of the Irish Engineering education system. By "curricular content", it is understood the syllabus content of a specific discipline or set of units taught to students [1]. The examination includes 23 engineering programmes from 6 institutions in Ireland that underwent accreditation between 2017-2019. In Ireland, ethics falls under the scope of programme outcome $\mathrm{E}$ formulated by the accrediting and professional body Engineers Ireland [11]. Outcome E requires programmes to provide evidence that graduates gained "(i) the ability to reflect on social and ethical responsibilities; (ii) knowledge and understanding of the social, environmental, ethical, economic, financial, institutional, sustainability and commercial considerations affecting the exercise of their engineering discipline; (iii) knowledge and understanding of the health, safety, cultural and legal issues and responsibilities of engineering practice, and the impact of engineering solutions in a societal and environmental context; (iv) knowledge and understanding of the importance of the engineer's role in society and the need for the commitment to highest ethical standards of practice; 
(v) knowledge, understanding and commitment to the framework of relevant legal requirements governing engineering activities, including personnel, environmental, health, safety and risk issues" [11]. The research questions set to address the aforementioned aim are (RQ1) what are the main themes employed in engineering ethics education, and (RQ2) how can these be interpreted in light of the different theoretical conceptualizations of engineering ethics education?

\section{RESEARCH METHOD}

To address the research questions of the study, the method employed is documentary analysis. An advantage of this method is that documents are a stable and non-reactive source of data [12], and can thus offer a broad picture of the type of curricular content purporting to ethics offered by the participant institutions.

Three main sources have been used for the documentary analysis,. A first source of data was the self-assessment rubric present in all documents submitted for accreditation by the participant programmes. Secondly, 17 of the 23 programmes have provided the description of their courses, either as an annex to the documentation submitted for accreditation (6 programmes) or part of the evidence presented during the accreditation events observed by the researcher (11 programmes). A third source of documentary data consists of the syllabus and the description of courses posted on the website of all participant programmes. The analysis is focused on 83 mandatory courses deemed by the participant programmes to have the highest contribution to meeting learning outcomes purporting to ethics. To identify these courses, we relied on a mandatory rubric in the documentation submitted by the programmes for accreditation, in which the programmes are required to selfassess with a numerical score ranging from 0 (no contribution) to 4 (strong contribution) how their courses meet each of the seven criteria for accreditation.

The process of collecting data was based on course descriptors containing learning outcomes and topics, as well as a rubric in the accreditation document in which programmes describe their contribution to outcome E. The process of analyzing data underwent several iterations until it generated a first codebook containing 28 topics employed for meeting the accreditation outcome purporting to ethics. During the second iteration stage, the initial thematic codes have been grouped and subsumed under broader categories, which led to the identification of 11 major thematic categories of curriculum content purporting to engineering ethics education. Table 1 mentions what type of curricular content is comprised by each of the 11 thematic categories identified.

Table 1. Coding of the content of engineering ethics education

\begin{tabular}{|l|l|}
\hline $\begin{array}{l}\text { THEMATIC } \\
\text { CATEGORY }\end{array}$ & CONTENT \\
\hline \multirow{3}{\text{Sustainability}}{} & $\begin{array}{l}\text { Referring to the principles of sustainable } \\
\text { development, environmental impact and } \\
\text { protection, climate change, carbon } \\
\text { management, energy efficiency, } \\
\text { renewable energy, life cycle analysis, } \\
\text { waste management, sustainable }\end{array}$ \\
\hline
\end{tabular}

\begin{tabular}{|c|c|}
\hline & $\begin{array}{l}\text { economic growth, eliminating poverty } \\
\text { traps }\end{array}$ \\
\hline $\begin{array}{l}\text { Health and } \\
\text { Safety }\end{array}$ & $\begin{array}{l}\text { Referring to health, workplace safety, } \\
\text { accident prevention, environmental and } \\
\text { societal hazard prevention, prediction } \\
\text { and risk assessment }\end{array}$ \\
\hline Legislative & $\begin{array}{l}\text { Referring to national and international } \\
\text { standards, directives, regulations, and } \\
\text { legislation, CE marking, product } \\
\text { liability, contract documents and } \\
\text { planning requirements, policy making, } \\
\text { intellectual property and patent law, } \\
\text { security, privacy and GDPR }\end{array}$ \\
\hline $\begin{array}{l}\text { Professional } \\
\text { ethics }\end{array}$ & $\begin{array}{l}\text { Referring to Codes of Ethics, } \\
\text { organization and regulation of the } \\
\text { profession, professional and public } \\
\text { bodies }\end{array}$ \\
\hline $\begin{array}{l}\text { Business } \\
\text { studies }\end{array}$ & $\begin{array}{l}\text { Referring to management, business, } \\
\text { finance, cost effectivenes, } \\
\text { organizational culture }\end{array}$ \\
\hline $\begin{array}{l}\text { Societal } \\
\text { context }\end{array}$ & $\begin{array}{l}\text { Referring to the cultural, economic and } \\
\text { socio political dimension of engineering, } \\
\text { science and technology studies, } \\
\text { globalization and international context, } \\
\text { diversity, implications of robotics, AI, } \\
\text { automated and autonomous systems }\end{array}$ \\
\hline Responsibility & $\begin{array}{l}\text { Referring to responsibility towards } \\
\text { society and the ecosystem, corporate } \\
\text { social responsibility }\end{array}$ \\
\hline Value design & $\begin{array}{l}\text { Referring to value design, universal } \\
\text { design, design centred on user needs and } \\
\text { characteristics }\end{array}$ \\
\hline Plagiarism & $\begin{array}{l}\text { Referring to referencing, plagiarism and } \\
\text { academic honesty }\end{array}$ \\
\hline $\begin{array}{l}\text { Ethical } \\
\text { theories }\end{array}$ & $\begin{array}{l}\text { Referring to ethical theories, ethical } \\
\text { dilemmas, ethical reasoning and } \\
\text { decision-making, computer ethics, cyber } \\
\text { ethics, environmental ethics }\end{array}$ \\
\hline $\begin{array}{l}\text { Humanitarian } \\
\text { engineering } \\
\text { and } \\
\text { community } \\
\text { service }\end{array}$ & $\begin{array}{l}\text { Referring to humanitarian engineering, } \\
\text { social commitment and community } \\
\text { engagement or service }\end{array}$ \\
\hline
\end{tabular}

\section{FINDINGS}

Our analysis found that three main themes dominate the engineering ethics curricula, being present in more than half of the courses self-assessed as having a strong contribution to the accreditation outcome E. As seen in Table 2, these themes are related to sustainability coverage (present in 59\% of courses), health and safety coverage ( $58 \%$ of courses) and legislation (p54\% of courses).

These themes are also present in a wide variety of course types, such as technical courses, design courses, professional formation courses, capstone projects, legal studies courses, business studies courses, as well as in work placement. The distribution of sustainability, health and safety and legislation topics seems to suggest that these are the preferred topics for integrating ethics across the engineering curriculum. 
Table 2. The distribution of ethics content $(n=83)$

\begin{tabular}{|l|c|c|}
\hline Thematic category & $\begin{array}{c}\text { TOTAL } \\
(\mathbf{n}=\mathbf{8 3})\end{array}$ & $\begin{array}{c}\text { OF } \\
\text { TOTAL }\end{array}$ \\
\hline Sustainability & 49 & $59 \%$ \\
\hline Health and Safety & 48 & $58 \%$ \\
\hline Legislation & 45 & $54 \%$ \\
\hline Professional ethics & 21 & $25 \%$ \\
\hline Business studies & 21 & $25 \%$ \\
\hline Societal context & 20 & $24 \%$ \\
\hline Responsibility & 19 & $21 \%$ \\
\hline Value design & 14 & $17 \%$ \\
\hline Plagiarism & 13 & $16 \%$ \\
\hline Ethical theories & 13 & $16 \%$ \\
\hline Humanitarian engineering & 1 & $1 \%$ \\
\hline and community service & & \\
\hline
\end{tabular}

With a presence in approximatively a quarter of the courses analyzed, professional ethics (25\%), business studies (25\%) and societal context (24\%) represent other three popular themes used in engineering ethics instruction.

Professional ethics includes coverage related to the code of ethics and the organization and regulation of the engineering profession. This curricular theme is addressed in $92 \%$ of the courses categorized as courses of professional formation, but has a weak presence in other type of courses. Inspired by the definition provided by Riley [13], professional formation courses are understood to address considerations regarding the development of students' engineering identity, their acculturation to the profession and its norms, knowledge of professional practice, as well as the development of professional skills and perspectives. Typically, these courses are first year courses which are part of the common syllabus for the entire student cohort, and can be considered to serve as a gateway for introducing engineering students to ethics.

Business studies are present in all courses dedicated to this topic, whose title points to management, business, finance and economics. This content can be also found in $67 \%$ of the professional formation courses. Societal context is most often covered in courses of professional formation, where it is present in $50 \%$ of this type of courses, and in technical courses, where it is present in $22 \%$ of the courses. Although the societal dimension of engineering has been found by evaluators to be present in the teaching materials, it is less prominent in assignments.

Responsibility is addressed in $21 \%$ of the courses selfassessed as having a strong contribution to the accreditation outcome purporting to ethics. This theme features most extensively in courses of professional formation, being present in $75 \%$ of courses of this type.

Value design is included in $17 \%$ of the courses self-assessed as having a strong contribution to the accreditation outcome purporting to ethics. It has the highest occurrence in design courses, being present in $40 \%$ of courses of this type, followed by technical courses, where is present in $17 \%$ of courses of this type.

Plagiarism is included in $16 \%$ of the courses self-assessed as having a strong contribution to the accreditation outcome purporting to ethics. Capstone projects have a high emphasis on this type of curricular content, as it is present in all courses of this type. Plagiarism is also present in $25 \%$ of courses of professional formation. As capstone projects are taking place in the final year of studies, and professional formation courses are typically a common first year course, it can be said that students are introduced to this curricular area early in their studies.

Ethical theories, dilemmas and reasoning is included in $16 \%$ of the courses self-assessed as having a strong contribution to the accreditation outcome purporting to ethics. It is present in $50 \%$ of the courses of professional formation, and also in $11 \%$ of technical courses.

Humanitarian engineering and community engagement is the theme which is the least represented in the engineering ethics curricula, being present in only $1 \%$ of courses. It is worth noting that this theme is present in extracurricular activities offered by the participant programmes across the country and Northern Ireland, under the form of the competition 'Where there is no engineer" organized by Engineers without Borders Ireland. The initiative aims to encourage engineering students to "design creative solutions to development challenges globally" and "improve resilience within communities." Among the projects designed by students are a solar powered battery bank, low cost heaters and a menstrual pad washing system for women living in refugee camps [14].

In examining the content of the courses in terms of the debates presented in the literature review, a major finding points to the extent of coverage of what the literature labels as macroethical issues. Sustainability, legislative and societal related coverage are among the themes most present in the engineering ethics curriculum. The strong presence of macroethical curricular content is consistent with the findings about ethics coverage revealed by the study conducted by [7]. Polmear et al's [7] investigation points to the prevalence in Western European Engineering programmes, compared to US programmes, of topics related to sustainability, the societal impact of technology and professional practice issues. This seems to suggest that compared to the US, the coverage of ethics by the participant programmes in Ireland is more geared towards macroethical topics.

Considering topics associated with the microethical approach, while safety is indeed the second most popular theme used to convey curricular content pertaining to ethics, receiving 60 mentions in 43 courses, the themes of plagiarism and ethical theories, which are traditionally associated with microethical approaches, are among the three least used themes. Curriculum content pertaining to ethics education does not bear as heavy emphasis on plagiarism in participant engineering programmes in Ireland as it does in the UK and Portugal, according to studies conducted by [5] and [15]. Ethical theories also have a low presence in the curricula of participant engineering programmes in Ireland, unlike the emphasis reported in studies conducted in US Engineering programmes [6]. 
It is important to note the attempt to encompass several themes in one course deemed to have a high contribution to the outcome purporting to ethics. There is an average of 3 themes addressed in each of the courses analyzed. Several courses describe the attempt to address ethics from both a micro and macroethical perspective. As Devon and Van de Poel [16] argue, the "social [macro] ethics approach and individual [micro] ethics approach do not exclude each other", and this is visible in many teaching interventions that were analyzed.

\section{CONCLUSION}

In examining the curricular content of the courses deemed to have a strong contribution to the accreditation outcome purporting to ethics, the study noted a particular emphasis on the incorporation of sustainability, health and safety and legislation throughout the engineering curriculum, as these topics are present in a variety of course types.

There are two major characteristics of the prevalence of teaching ethics through the prism of sustainability, legislation and safety related topics. First, compared with the other thematic areas identified, these themes have a particular strong presence in technical courses. Second, these themes are closely linked to the conceptualization of ethics in practical terms and the instruction through realistic case studies reflecting contexts of engineering practice.

Furthermore, by examining the curricular content of courses in terms of existing research, the study notes a low engagement with philosophical theories, similar to the findings of Hess and Fore [17]. While professional ethics aspects such as rules and codes are often touched upon, these do not represent the main focus for the integration of ethics, as Hess and Fore [17] found. It can thus be argued that while the development of propositional and theoretical knowledge is the locus of concern when exposing student to the technical dimension of engineering ([18], p.263), in engineering ethics education the emphasis is on a practical and hands-down ethics instruction, by enabling students' situational responses in decision making and in the context of the design of engineering artefacts.

Reflecting on the integration of ethics through sustainability, it is considered that higher education institutions are "far from reorienting themselves towards sustainability" and that sustainability appears to be "integrated in a piece-meal fashion" ([19], p.64). While it cannot be said that the implementation of sustainability is carried in a systematic and even manner in the programmes in the study, what does emerge is a desire to address ethical issues through the prism of sustainability. Setting a foundation for ethics education rooted in sustainability topics is seen by Biedenweg et al ([20], p.7) as a critical component in the education of engineers because it provides "a structure for understanding the moral basis for decisions about which technique or strategy to employ".

Having highlighted the popularity of engineering ethics instruction through sustainability and Health and Safety topics, as well as the focus of legislative topics on standards, an advantage of this approach is that it can be tailored to the expertise of engineering faculty ([21], [22]). These themes can be considered to suit the expertise of engineering instructors, more than ethical theory would, thus addressing a common challenge rooted in the lack of familiarity and expertise of engineering instructors with ethics ([15]; [23]; [24]). An issue then is how we can use this appetence of engineering instructors to teach ethics through sustainability, safety and legislation related coverage as a mechanism for broadening engineering education, as to more fully integrate the technical, the social, and the environmental dimensions of engineering in one comprehensive form of education, as suggested by Nicolaou et al [25].

Another key finding is the extent to which what might be considered macroethical issues are included in engineering education in Ireland. For example, if we combine items related to sustainability, legislative aspects, the societal dimension of engineering, responsibility and community engagement, we can see that these themes associated with the macroethical approach outnumber themes associated with the microethical approach, such as health and safety, professional ethics, ethical theories and plagiarism. Existing research points out that a focus on sustainability and policy may facilitate the broadening of engineering ethics education beyond a micro ethical approach ([26], [27], [28], [29]). The integration of these thematic areas through a macroethical lens is considered to empower students to address the pressing socio-political, socio-economic and biophysical aspects of environmental problems ([30], [31]).

It is notable the overarching focus of professional formation courses on curricular content purporting to professional ethics, responsibility and the societal context. This emphasis can be explained in light of the aims promoted by professional formation courses of introducing students to the role of the professional engineer and the nontechnical specifications of engineering. It can thus be suggested that engineering programmes should promote the implementation of ethics in dedicated courses, such as professional formation courses, in order to facilitate the socio-technical enculturation of students into the engineering profession. A hybrid model of implementing ethics both in courses of professional formation and throughout the curriculum can provide a more comprehensive model of ethics education, which has the potential of making students aware of the core nature of ethical concerns for engineering practice, and the intertwining of ethical and technical knowledge and skills.

The study also brings to light the existing confusion as to what counts as ethical content. The theme of Health and Safety, for example, revealed itself to lead to problematic understandings regarding whether its coverage falls under the scope of ethics or not. Based on the module descriptors and evidence in support of how the programmes meet the accreditation outcomes, while some course developers did not associate content related to Health and Safety as falling under the scope of ethics, other course developers interpreted the contribution of their course to ethics solely through the lens of its mathematical and technical application, with no discussion of the safety considerations involved by these calculations. A similar confusion was remarked in connection with the coverage of legislative issues such as intellectual property and protected disclosures, with some course developers not including this curricular content under the scope of ethics education. The confusion as to what counts as 
engineering ethics education has been previously pointed out by Reed et al ([32], p. 169), especially in connection to topics such as "copyright, building codes and other similar concepts covered in technology education."

As the present study has identified three topics (sustainability, safety and legislation) amenable to the implementation of ethics across the curriculum, further research can examine the integration of ethics topics and curricular units at the level of specific programmes and institutions. A particular focus can be given to case study research of programmes that report positive results or describe initiatives for implementing ethics across the curriculum, similar to those exposed by Riley et al [33] and Mitcham \& Englehardt [8]. Further research is also needed to explore the challenges in implementing curricular themes which have a rare presence in engineering ethics education, such as humanitarian engineering and community engagement, as well as presenting best practice examples that can inspire instructors and programme chairs.

Finally, given the diminished familiarity of engineering instructors with ethics and the confusion as to what falls under the scope of engineering ethics, education, a recommended avenue for further research is to provide an indepth exploration of the challenges experienced by lecturers for teaching ethics, as well as to examine the effectiveness of different strategies countering these.

\section{REFERENCES}

[1] Lattuca, L.R. \& Stark, J.S. (2009). Shaping the college curriculum: academic plans in context, San Francisco, CA: Jossey-Bass

[2] Lynch, W.T., \& Kline, R. (2000). Engineering practice and engineering ethics. Science Technology and Human Values, 25(2), 195-225.

[3] Haws, D.R. (2001). Ethics instruction in engineering education: A (mini) meta-analysis. Journal of Engineering Education, 90 (2), 223229

[4] Kline, R. (2001). Using history and sociology to teach engineering ethics, IEEE Technology and Society, 20(4), 13-20

[5] Atesh, M., Baruah, B. \& Ward, T. (2017). A new framework for measuring the ethical awareness and perception among engineering students in Higher Education. 6th New Perspectives in Science Education, Florence,Italy

[6] Colby, A., \& Sullivan, W. (2008). Ethics Teaching in Undergraduate Engineering Education. Journal of Engineering Education, 97(3),327338

[7] Polmear, M., Bielefeldt, A., Knight, D., Canney, N. \& Swan, C. (2019) Analysis of macroethics teaching practices and perceptions in engineering: a cultural comparison, European Journal of Engineering Education

[8] Mitcham, C. \& Englehardt, E. E. (2019). Ethics across the Curriculum: Prospects for Broader (and Deeper) Teaching and Learning in Research and Engineering Ethics. Science and Engineering Ethics, 25(6), 17351762

[9] Bielefeldt, A.R., Canney, N.E., Swan, C., \& Knight, D. (2016), Efficacy of Macroethics Education in Engineering. 2016 ASEE Annual Conference and Exposition, New Orleans, Louisiana

[10] Holsapple, M. A., Carpenter, D. D., Sutkus, J. A., Finelli, C. J. \& Harding, T. S. (2012), Framing Faculty and Student Discrepancies in Engineering Ethics Education Delivery. Journal of Engineering Education, 101,169-186.

[11] Engineers Ireland. (2007). Accreditation Criteria for Engineering Education Programmes.
[12] Bowen, G.A. (2009). Document analysis as a qualitative research method. Qualitative Research Journal, 9(2),27-40

[13] Riley, D. (2014). Professional Formation of Engineers. National Science Foundation - Spring 2014: ENG Advisory Committee Meeting

[14] McCarton, L., O'Hógáin, S. (2018) Where There Is No Engineer Designing for Community Resilience. Development Technology in the Community (DTC) Research Group, Technological University Dublin (DIT) \& Engineers Without Borders (EWB) Ireland, 2018.

[15] Monteiro, F., Leite, C. \& Rocha, C. (2016). Ethics and Civic Education in the Curriculum of Engineering courses in Portuguese Higher Education System. 8th International Symposium on Project Approaches in Engineering Education and 14th Active Learning in Engineering Education Workshop Proccedings

[16] Devon, R. \& Van de Poel, I. (2004). Design ethics: The social ethics paradigm, International Journal of Engineering Education, 20(3),461469

[17] Hess, J.L. \& Fore, G.A. (2018). A systematic literature review of US engineering ethics interventions. Science and Engineering Ethics, 24(2), 551-583

[18] Radcliffe, D. (2006). Shaping the discipline of engineering education. Journal of Engineering Education 95(4),263-64

[19] Lambrechts, W., Mulà, I., Ceulemans, K., Molderez, I., \& Gaeremynck, V. (2013). The integration of competences for sustainable development in higher education: an analysis of bachelor programs in management, Journal of Cleaner Production, 48, 65-73.

[20] Biedenweg, K., Monroe, M.C. \& Oxarart, A. (2013). The importance of teaching ethics of sustainability", International Journal of Sustainability in Higher Education, 14(1), 6-14

[21] Walczak, K., Finelli, C. J., Holsapple, M. A., Sutkus, J. A., Harding, T. S., and Carpenter, D. D. (2010). Institutional obstacles to integrating ethics into the curriculum and strategies for overcoming them. Proceedings of the 2010 ASEE Annual Conference \& Exposition, Louisville

[22] Sinha, S.K., Thomas, R., Kulka, J.R. (2007). Integrating ethics into the engineered construction curriculum. Journal of Professional Issues in Engineering Education and Practice, 133, 291-299

[23] Romkey, L. (2015, June). Engineering, Society, and the Environment in the Teaching Goals and Practices of Engineering Instructors. 2015 ASEE Annual Conference \& Exposition, Seattle, Washington

[24] Polmear, M., Bielefeldt, A.R., Knight, D., Canney, N \& Swan, C. (2018). Faculty perceptions of challenges to educating engineering and computing students about ethics and societal impacts, Proceedings of the ASEE Annual Conference \& Exposition

[25] Nicolaou, I., Conlon, E. \& Bowe, B. (2018) Into the Deep: The Role of Paradigms in Understanding Engineering Education for Sustainable Development. Irish Journal of Social, Economic and Environmental Sustainability. 1 (2), 23-41

[26] Gorman, M. E., Mehalik, M. M. \& Werhane, P. H. (2000). Ethical and Environmental Challenges to Engineering, Englewood Cliffs, NJ: Prentice Hall.

[27] Byrne, E.P. (2012). Teaching engineering ethics with sustainability as context, International Journal of Sustainability in Higher Education, 13(3), $232-248$

[28] Bekker, R. \& Bombaerts, G. (2017). Introducing broad skills in higher engineering education: the patents and standards courses at Eindhoven University of Technology. Technology and Innovation, 19, 493

[29] Herkert, J. R. (2000). Ethical Responsibility and Societal Context: Integrating Ethics and Public Policy Considerations in the Engineering Curriculum, 30th Annual Frontiers in Education Conference

[30] Warburton, K. (2003). Deep learning and education for sustainability, International Journal of Sustainability in Higher Education, 4(1), 4452

[31] Bender, H. (2012). Reshaping Environments - an opportunity for envisioning the future', in H. Bender (Ed.), Reshaping Environments, An interdisciplinary approach to sustainability in a complex world, Cambridge University Press, Cambridge, 1-13

[32] Reed, P. A., Hughes, A., Susan, P., \& Stephens, D. I. (2004). The status of ethics in technology education. In R. B. Hill (Eds.), Ethics for Citizenship in a Technological World. Peoria, IL: Glencoe/McGrawHill, 163-186

[33] Riley, D., Ellis, G., and Howe, S. (2004). 'To Move People From Apathy': A MultiPerspective Approach to Ethics Across the Engineering Curriculum. In Proceedings of American Society for Engineering Education Annual Conference. 